\title{
Sciendo
}

RURAL SUSTAINABILITY RESEARCH 45 (340), 2021

ISSN - 2256-0939

(c) Latvia University of Life Sciences and Technologies, all rights reserved http://www.Ilu.Iv/en/

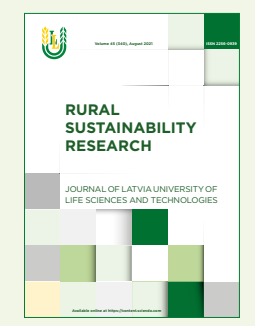

Received: 2 March 2021

Revised: 12 April 2021

Accepted: 7 May 2021

\section{Resilience of Milk Supply Chains during and after the COVID-19 Crisis in Latvia}

\author{
*Irina Pilvere', Ilze Upite ${ }^{2}$, Aina Muska ${ }^{3}$, Kristaps Zdanovskis ${ }^{4}$, Aleksejs Nipers ${ }^{5}$, Lana Janmere ${ }^{6}$ \\ 1,2,3,5,6 Latvia University of Life Sciences and Technologies, Liela street 2, Jelgava, Latvia \\ ${ }^{4}$ Project Coordinator, EU Office for Agriculture and Rural Development, Rigas street 34, Ozolnieki, Latvia
}

\begin{abstract}
The impacts of the COVID-19 pandemic on national economies are characterized as the worst economic turmoil in recent years, as economic growth slowed to the level of the 2008 global financial crisis. At the end of 2019 and the beginning of 2020, economic growth surveys did not project that the novel virus could have a negative impact on economic growth. As a result of the rapid spread of the virus and the increase in the number of infection cases, national governments took strict measures to limit the spread of the virus, which led to a significant deterioration in the economic situation in all industries of the economy. Agriculture plays an important role in providing food to the country's population, yet the pandemic made a negative impact on sales volumes and prices in the domestic and international markets. The research aims to assess the impacts of the pandemic on milk supply chains in Latvia and come up with solutions to stabilizing the situation in the dairy sector. The national restrictions to combat the pandemic also hampered the dairy sector concerning the sale of raw milk and finished products in foreign markets, thereby leading to overproduction and stockpiling of the finished products, price dumping and a significant decrease in milk purchase prices to or below the production cost level for many dairy farms. Although there is no indication that the pandemic would lead to a decrease in the numbers of livestock and farms or output in early 2021, it is too early to assess the overall impact of the pandemic on dairy farming, as uncertainty over the duration of pandemic restrictions is a major risk to farm survival. The operation of the dairy sector was stabilized by means of the support provided by the government, as well as the farms' accumulated financial and feed resources. In order to identify future challenges for milk supply chains, the research performed an analysis of operational risks for milk producers and processors to identify the most important risks and design recommendations for their elimination. The longer there is uncertainty about the return of the dairy sector to pre-pandemic output levels, the more likely it is that the pandemic is going to lead to a decrease in the numbers of dairy livestock and farms.
\end{abstract}

Keywords: COVID-19, impact on agriculture, dairy sector resilience, supply chains.

\section{Introduction}

One of the largest global economic shocks in recent times was caused by the COVID-19 or coronavirus pandemic. It was first discovered in China in late 2019 and spread around the world in a very short period. The World Health Organization declared an emergency on 30 January 2020 and a pandemic on 11 March 2020 (World Health..., 2020).

The measures taken by countries to contain the pandemic made enormous pressure on their economies, thereby changing the public's daily habits, mobility etc. and revealing weaknesses in social care, access to basic necessities and food, logistics and raw materials. The countries implemented a number of measures to consolidate their health care sectors, restrict public movement and contacts, support the private and business sectors, etc. (OECD-FAO, 2020).

Any economic crisis also makes negative impacts on agricultural output, processing and trade, and contributes to price volatility. In relation to the impacts of previous economic crises on the agricultural sector and food security, the Food and Agriculture

\footnotetext{
* Corresponding Author's email: Irina.Pilvere@1lu.lv
} 
Organization of the United Nations (FAO) (2006; 2009) states that countries need to learn from mistakes and assess their readiness to supply food that is physically and financially accessible and safe and meets nutritional requirements. R.Gros et al. (2000) and P.B.R.Hazell (2009) point out that the theoretical debate on nutrition and food security on a global scale has been going on for more than 50 years and have conclude that technological advances have boosted output and stabilized food availability, as well as that in times of crisis or emergency, access to adequate food is a greater problem for certain social groups due to their lower buying power.

A.Perrin and G.Martin (2021) emphasize that identifying and developing resilient farming and food systems has emerged as a top priority during the Covid-19 pandemic. The availability of food is not limited to agricultural output, and it should be viewed in conjunction with the interaction of three levels defined by R.Gros et al. (2000): 1) household sector (micro), 2) production and processing sector (meso) and 3) national policies (macro). For example, the COVID-19 situation has showed that imprudent macro-level restrictions, such as border closures or lockdown in certain sectors, decrease sales of meso-level products or the buying power of micro-level consumers, thereby jeopardizing food availability; consequently, farmers fail to reach the minimum earnings level, which might create the risk of stopping agricultural activity by them. The resilience of supply chains for key primary products during a crisis needs to be assessed at the national level through an in-depth risk analysis.

Research on the impacts of COVID-19 on public health, the economy, economic growth, food supply chains, food availability and safety, etc. is a new research problem that is going to remain relevant in the coming years (Elsahoryi et al., 2020; Cavallo, Sacchi\&Carfora, 2020; Bracale \& Vaccaro, 2020). The pandemic is going to continue in 2021, affecting all countries; therefore, it is too early to make a final assessment of its impacts. National-level research is needed first of all to assess and compare the impacts of the pandemic on a regional and global scale. Q.Wang et al. (2020) point out that ... this pandemic has heavily affected the dairy industries in China and the United States through similar mechanisms, such as decreased farmgate milk prices, disruption and difficulties of moving milk within the supply chains, worker shortages, increased production costs, and lack of operating capital. Accordingly, the research aims to assess the impacts of the pandemic on milk supply chains in Latvia and come up with solutions to stabilize the situation in the dairy sector.
To achieve the research aim, the following specific research tasks were defined: 1) to describe the impacts of the pandemic on economic development at the global and European Union (EU) levels; 2) to assess the impacts of the pandemic on the agricultural sector and milk supply chains in Latvia; 3 ) to analyze the main risks to the operational stability of milk producers and processors during the pandemic.

\section{Materials and Methods}

The authors used related research papers and information provided by the Central Statistical Bureau (CSB), FAO, the Organization for Economic Cooperation and Development (OECD), the World Bank (WB), the International Monetary Fund (IMF), the European Commission (EC), Eurostat and the Ministry of Agriculture of the Republic of Latvia (MoA). The research methods used: monographic and descriptive, analysis and synthesis, statistical analysis and logical construction. Potential risks for milk supply chains were identified and recommendations for mitigating the impacts of the risks were designed based on the statistical data and related research papers. Due to the limited statistical data, the research results do not relate to the same period of analysis.

\section{Results and Discussion}

1. Impacts of COVID-19 on global and European economic development

At the end of 2019, WB and OECD experts drew attention to an overall decrease in global GDP compared with the low growth rate during the 2008 global financial crisis. However, at the end of 2019, the experts and the IMF projected the global economic growth rate to be $3.4 \%$ in 2020 and $3.5 \%$ in 2021 . At the beginning of 2020, the experts lowered the projection for growth to 3.3\% (World Bank, 2021; IMF, 2020; OECD, 2019).

At the beginning of 2020, the EC pointed to stable economic growth in the euro area, projecting $1.2 \%$ growth in 2020 and 2021 and $1.4 \%$ growth in the EU as a whole in 2020 and 2021, indicating that the economy was stable and the main risks were uncertainty in international trade. Since the introduction of the euro in the EU in 1999, this has been the longest period of steady growth in the EU (European Commission, 2020). No expert from any organization in early 2020 saw the threat of the COVID 19 pandemic to economic growth, indicating that it was too early to discuss the potential impacts of the virus.

As the pandemic rapidly spread around the world at the end of the first quarter of 2020, global and regional growth projections changed significantly following the Great Lockdown to curb the virus. The 


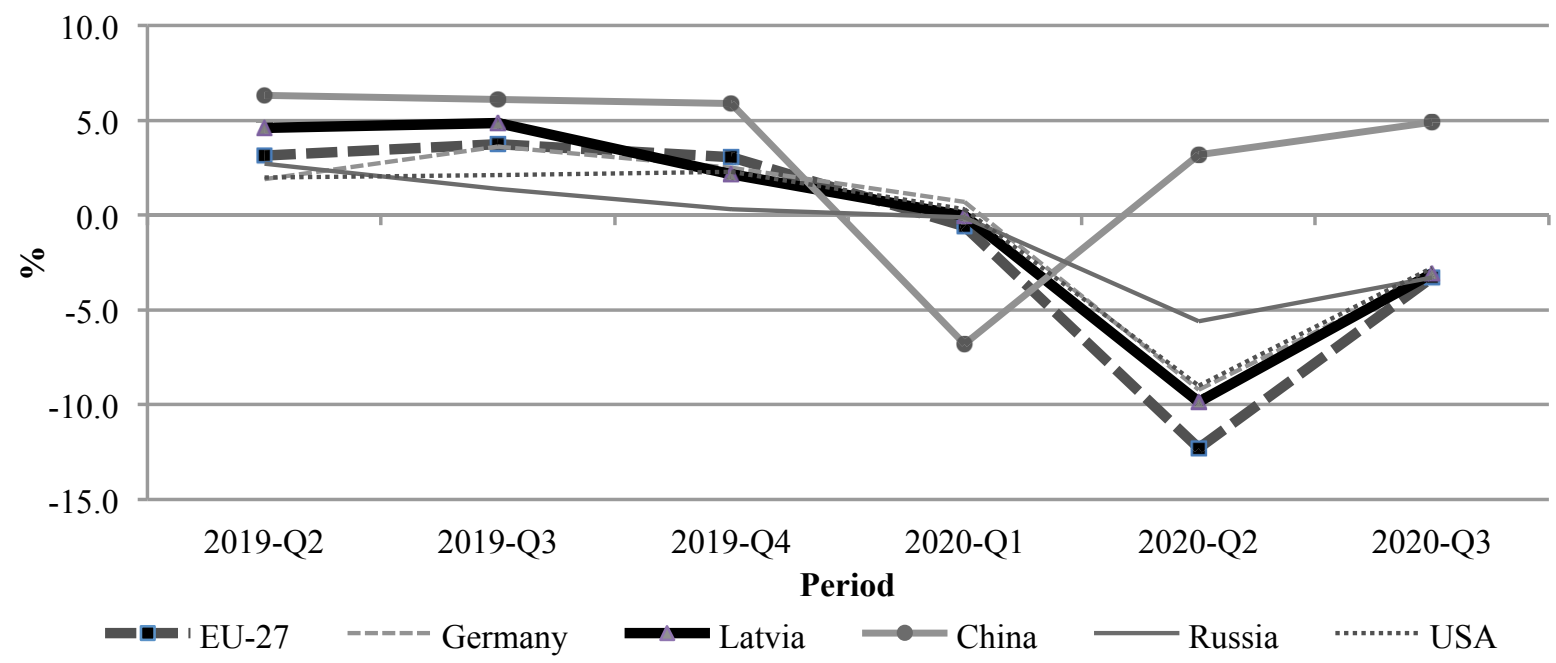

Source: authors' construction based on Eurostat, 2021, OECD, 2021 and Statista, 2021

Figure 1. GDP growth, quarterly changes compared with the same period of the previous year in the period 2019Q2-2020Q3, \% (unadjusted data).

downturn in economic activity during the pandemic was the fourth largest economic recession since the two world wars and the Great Depression (Great Depression) (World Bank, 2021).

According to the WB (2021) experts, the impacts of the pandemic in various regions of the world varied, depending on the economic situation in the countries before the pandemic, the extent of restrictions adopted, their capability to adapt to new conditions, the countries' dependence on international trade, etc. At the beginning of 2020, economic experts had not predicted significant impacts of the pandemic on the EU economy yet. The deterioration of the economic situation in China was already observed at the end of 2019. Following the fast spread of the coronavirus, the economic situation in the rest of the world deteriorated in the second quarter of 2020 (Figure 1). According to IMF estimates, negative GDP growth over the same period last year was observed in virtually every country in the world, except China, which had already recovered from the first wave of the pandemic and some developing countries in Latin America and Africa (IMF, 2021). The average decrease in EU GDP growth in the second quarter of 2020 compared with the second quarter of 2019 was $12.3 \%$, in Latvia the GDP decrease was 9.9\%, whereas in China, for example, a $3.2 \%$ GDP growth rate was reported. In the third quarter of 2020, economic activity increased in the EU owing to the lifting of movement restrictions and many other restrictions, and GDP in the EU-27 increased by $10.7 \%$ and in Latvia by $13.2 \%$ compared with the second quarter of the same year, yet it was $3.1 \%$ lower than in the $3 \mathrm{rd}$ quarter of 2019 . The IMF forecasts a gradual increase in GDP and an economic recovery in 2021. In some sectors, such as health care, growth was reported during the pandemic, yet it failed to offset the overall economic downturn.

Globally, the unifying activity to contain the pandemic was the closure of national borders, which made the most significant impacts on the tourism and cultural industry, air transport, the catering industry and related service activities, such as product suppliers, oil traders, outsourcers at airports and hotels, etc. The restrictions to combat the pandemic were aimed at reducing the movement and assembly of people in confined and small spaces.

Historically, in times of various economic and political tensions, the role of agriculture in supplying food and raw materials for production increased, and the food industry was a driver of the economic recovery. Medium-term forecasts by FAO and the OECD (2020) indicate that the pandemic can only have a negative impact on agricultural primary production in the short term, and this situation is a good example of countries' preparedness to provide food for future crises. The average value added of the agricultural sector in the EU in the third quarter of 2020 was $2.1 \%$, increasing by 0.5 and 0.1 percentage points in the first and second quarters of the same year, respectively; in absolute terms, the value added of the sector increased by EUR 15.5 billion and EUR 8.6 billion, reaching a value of EUR 62.2 billion. The increase in the proportion of agricultural value added in the total GDP of the EU was facilitated by a boom in the purchase of necessities at the beginning of the pandemic and the decline in economic activity in other sectors (tourism, catering, aviation, etc.). Although the value added of the agricultural sector in the first three quarters of 2020 
was $0.5 \%$ lower than that in 2019 , in absolute terms, the decrease in the value added of the sector was lower than that in the total GDP of the EU.

From the perspective of food security, FAO (2020) points out that the pandemic has made a significant impact on agriculture, disrupting food supply chains, reducing agri-food prices on global markets, increasing public poverty, reducing populations' buying power and reducing access to adequate food. In contrast, R.Siche (2020) and C.Elleby et al. (2020) indicate that, from the perspective of food security, the pandemic has made a greater impact on the populations of developing countries, where there is food insecurity compared with developed countries, incl. the EU. L.Pena-Levano, G.Melo \& S.Burney (2020) add that in developed countries, the negative impacts of the pandemic on agriculture were caused by forced restrictions - closure of schools and restaurants, labour shortages, restrictions on the movement of people, etc. The impacts of the pandemic on the agricultural sector or its industries in each region should be assessed differently, depending on the role of the sector in exports, the level of self-sufficiency in food, the capability to adapt to changing consumer behaviours, the capability to reorient production, economic recovery pace, etc. Unlike the 2008 global economic crisis, strict operating restrictions were imposed during the COVID-19 pandemic, and the competitiveness of businesses depended on their capability to adapt to the requirements set. In research studies, food security and self-sufficiency are analysed at two levels: food production (farmers) and food processing (processors), both forming a supply chain. At both levels, the main challenges involved ensuring hygiene and distance; steady supply chains; access to production resources; availability of labour (due to restrictions on movement); direct-to-consumer marketing (D2C); continuous availability of products to consumers, etc. (FAO \& CELAC, 2020; TAG, 2020).

\section{Impacts of the pandemic on the economy and agriculture in Latvia}

The fast spread of the pandemic and the measures taken to contain it in Latvia have also made a negative impact on the country's economic situation. During the first wave of the pandemic, from 12 March to 9 June 2020, as in other countries, the border was closed, face-to-face training was interrupted, the HoReCa sector was closed, the organization of cultural events was restricted and so on. Due to low morbidity rates, a number of restrictions were lifted during the summer, but COVID-19 morbidity rates rose sharply in the autumn, leading to a second lockdown. In the second and third quarters of 2020, the GDP of
Latvia decreased by $3.1 \%$ and $9.9 \%$ on a year-on-year basis, and the decreases were 2.4 and 0.2 percentage points lower than the EU averages in the respective period (Figure 1). After lifting the first restrictions, GDP grew by $13.2 \%$ in the third quarter of 2020 compared with the previous quarter of the same year (Eurostat, 2021).

A decrease in economic activity in the second quarter of 2020 was reported in almost all industries of the economy, yet the largest year-on-year decrease was reported for accommodation and food service activities, 63.4\% (NACE Rev 2, section I), arts, entertainment and recreation $46.3 \%(\mathrm{R})$, transportation and storage $26.6 \%(\mathrm{H})(\mathrm{CSB}, 2020 \mathrm{a})$. The lifting of restrictions contributed to a quarter-on-quarter increase in GDP in the third quarter of 2020, with the highest increase reported for arts, entertainment and recreation services, $50.4 \%(\mathrm{R})$ and accommodation and catering services $129.4 \%$ (I); the economic activity also increased in the transport sector $(\mathrm{H})$ and the construction sector (F). A comparison of the third quarter with the corresponding quarter of the previous year reveals that a decrease in GDP was reported in all industries of the economy, except agriculture $(A)(+6.3 \%)$, trade $(G)$ $(+1.7 \%)$, health care (Q) $(+5.1 \%)$, yet the largest decrease was reported for catering and accommodation services (I), 28.6\%, cultural and entertainment services (R), 22.4\%, and logistics (H), 14.7\% (CSB, 2020b).

Just like in other countries, in Latvia agriculture plays a strategic role in food security, economic growth and exports. In the 3rd quarter of 2020 compared with the corresponding quarter of the previous year, the value added of agriculture increased by $6.3 \%$, and the proportion of the sector in the total GDP increased by 0.37 percentage points to $4.49 \%$. An analysis of the value added of agriculture by quarter in previous years reveals that there were no significant differences, with the seasonal value remaining the highest in the third quarter. If analysing the value added of agriculture by year, one should also take into account the output of agriculture and sales prices, which are affected by a number of factors, such as weather, demand in international markets, prices at commodity exchanges, etc.

The joint decision of EU Member States to close the borders to contain the pandemic reduced foreign trade and the availability of labour from other countries. In the second quarter of 2020, the total volume of domestic exports decreased by $10.8 \%$ on a quarter-on-quarter basis, yet increased by $3.5 \%$ on a quarter-on-quarter basis in the following quarter. In the $1^{\text {st }}$ quarter of 2020 , the exports of agricultural commodities and food increased by $4 \%$ compared with the first quarter of the previous year, whereas in the 
next quarter they decreased by $12 \%$. In the $2^{\text {nd }}$ quarter of 2020, exports by the main export-oriented industries decreased: $13 \%$ for milk and dairy products, $35 \%$ for cereals, $17 \%$ for beef and 6\% for pork (Ministry of Agriculture, 2020a). Additional impacts on the food industry were made by the restrictions imposed on the HoReCa sector, the cessation of face-to-face activities in schools and kindergartens, lower product sales and increased stocks for product manufacturers, thereby leading to additional storage costs. This situation particularly affected the companies specializing in the production of food in large packs for the public sector, which is not convenient for households. Such companies had to repack their products to be suitable for the household sector or temporarily reduce their operation. In addition, changes in consumer habits had to be taken into account, as the consumers preferred basic necessities with a longer shelf life and less needed high value-added foods. Although farmers in Latvia produced enough agricultural products for processing, meat processing companies bought meat at commodity exchange prices that, during the first wave of the pandemic in the EU, were below the production cost for national producers. Despite possible difficulty in importing raw materials, companies purchased the raw materials needed for production at low commodity exchange prices, which was driven by overproduction in the EU. Problems in the agricultural sector were also indicated by the support programme launched by the Ministry of Agriculture for the most affected agricultural industries, with most of the support being intended for dairy farming.

\section{Milk supply chains in Latvia}

Dairy farming, accounting for $19.8 \%$ of the total value of agricultural output, was the second largest agricultural industry in Latvia after grain farming $(34.3 \%)$ in 2019 . By its nature, livestock production is a more complex agricultural industry than crop production, as it is not possible to stop production immediately and regulate the volume of production in this industry; compared with crop production, it requires to employ a relatively larger number of employees, and it also requires a regular presence of employees. Any economic crisis causes pressure on milk supply chains through falling milk prices. In Latvia, the dairy sector was significantly affected in 2014 by an export ban imposed by the Russian Federation, which had an impact on milk production in 2015 and 2016, as well as by unfavourable weather conditions (rainfall) in 2017, thereby creating significant problems for product sales and feed production, which resulted in a decrease in the number of dairy farms. In addition, during the COVID-19 pandemic, the operation of dairy farms depended on the health of their workers, as additional biosecurity measures were introduced, and if necessary, the farms redesign their worker operations to ensure the distancing of their workers. Any turmoil in the dairy sector over a long period of time makes many farms decide to discontinue farming.

Since the restoration of second independence in 1991, the numbers of dairy cows and farms in Latvia have tended to decrease, incl. also after the accession to the EU in 2004 and the availability of various EU financial instruments. In 2019 compared to 2002, the

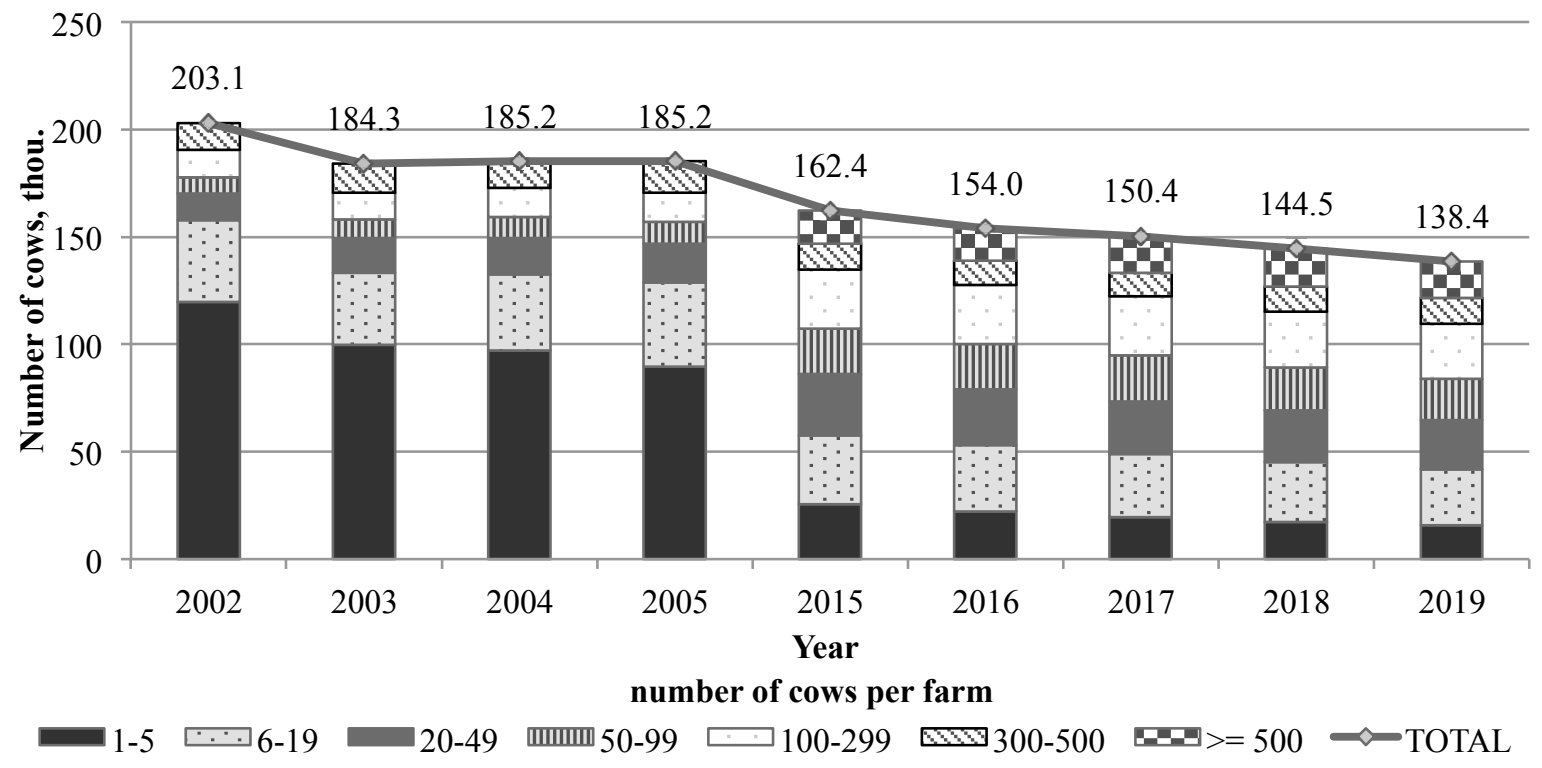

Source: authors' construction based on CSB, 2020c

Figure 2. Number of dairy cows by farm size and the total cows in 2002-2005 and in 2015-2019, thou. 


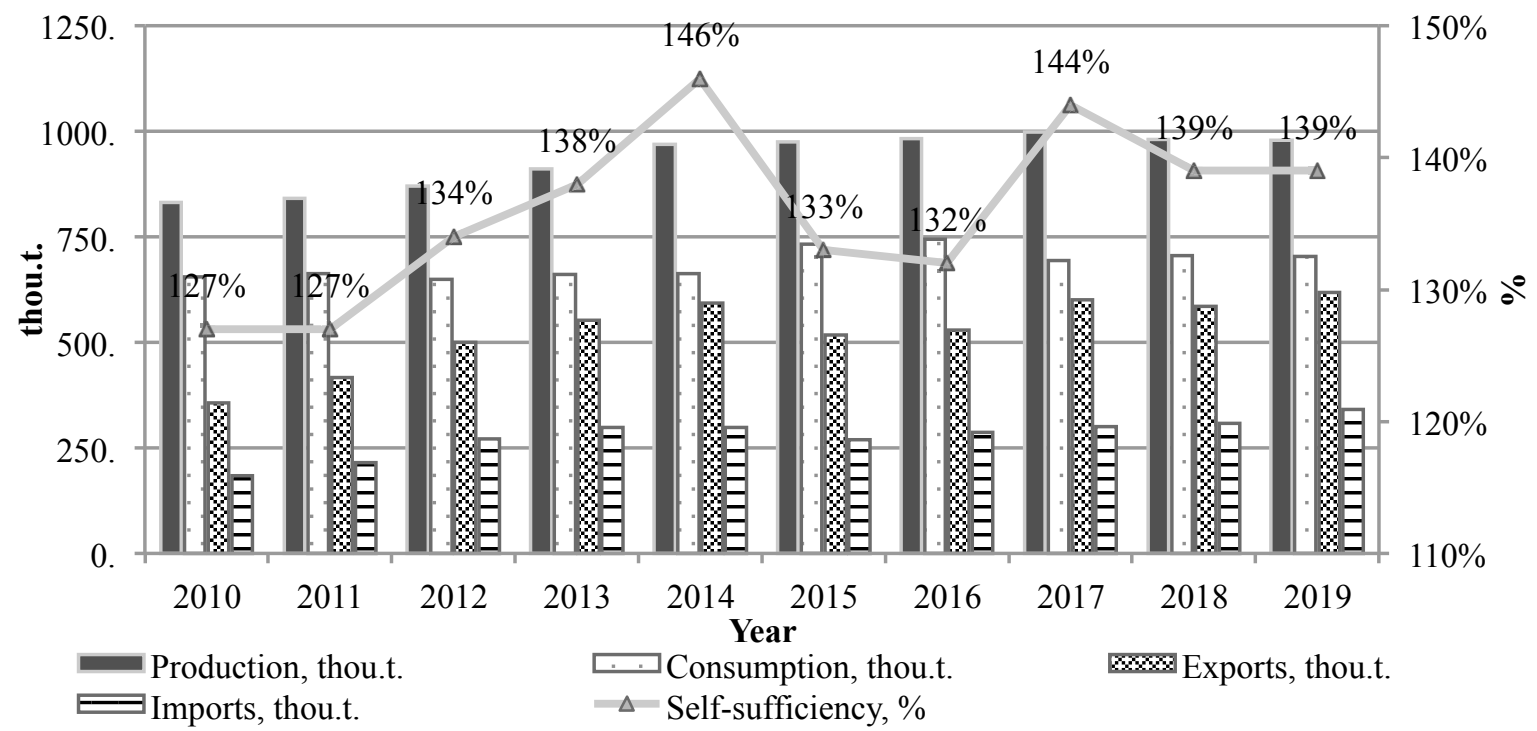

Source: authors' construction based on the Ministry of Agriculture, $2020 \mathrm{~b}$

Figure 3. Quantity of milk produced, exported, imported and consumed and self-sufficiency in dairy products in the period 2010-2019, thou.t and \%.

total number of dairy cows decreased by 64.7 thou. or $31.9 \%$, and the total number of dairy farms in the same period decreased by 58.8 thou. or $82.6 \%$.

The most significant decrease in the numbers of dairy farms and cows was observed in the group of farms with up to 5 cows; in the same period, the number of farms decreased by 58.5 thou. or $87 \%$, and the number of cows by 51.3 thou., whereas an increase was observed in the group of farms with the number of cows in the range of 20-49 (Figure 2). The main factors reducing the number of small dairy farms were the low competitiveness due to the aging of their agricultural equipment, their inability to adapt to the animal welfare, hygiene and manure management requirements set, the high proportion of manual work and the problem with generational change.

With EU support instruments being available, modern dairy farms with the number of cows larger than 500 emerged. In 2019, there were 20 such farms $(0.2 \%$ of the total) with 16.8 thou. cows $(12.2 \%$ of the total). At the same time, the average number of cows per farm has increased from 2.9 to 11.1 in the period 2002-2019. The farm structure of Latvia is still characterized by a large number of home farms having a small number of cows, and in 2019 there were only $1.7 \%$ farms with more than 100 cows, making up 39\% of the total cows.

An analysis of changes in the number of dairy cows in 2002-2020 reveals that there is no reason to consider that COVID-19 contributed to the decrease in the number of dairy cows. The most significant decrease in the number of cows compared with the previous year was reported during the 2008 milk price crisis when the number of cows decreased by $5 \%$. In 2020 , however, the number of cows decreased by $1.62 \%$ compared with 2019 and by $4.19 \%$ compared with 2018.

Nevertheless, it should be taken into account that milk output exceeds milk consumption in Latvia because approximately $1 / 3$ of the total milk output is processed for the domestic market, $1 / 3$ of raw milk is exported to Lithuania and Estonia and $1 / 3$ is processed for exports.

Despite the decrease in the total number of dairy cows in Latvia, the quantity of milk produced tended to increase owing to improvements in livestock genetics and the cultivation of herds. Since 2014 in Latvia, the output of milk has reached almost 1 million tons per year (Figure 3). Due to the fragmented structure of farms, the quantity of milk produced varies from month to month. The highest milk yield is reported in summer months when the cows are grazing and are fed wholesome diets, which is not the case during winter, especially on small farms. In total, 981 thousand tons of milk were produced in Latvia in 2020, 0.68\% more compared with 2019 and $1.26 \%$ more compared with 2018, with the average milk yield per cow increasing from to $7.8 \mathrm{t}$ in 2020. An analysis of the output of milk by month in 2020 reveals that COVID-19 has not affected the milk production. At the beginning of the pandemic, in March and April, the milk output was on average $2.6 \%$ lower than in 2019 , yet $1.9 \%$ higher in the period from May to the end of the year. 
Overall, there is milk overproduction in Latvia and the EU, which contributes to milk price dumping even under difficult conditions. Until 2015, milk production in the EU was regulated by quotas, setting a maximum quantity of milk to be sold for each farm. Before the abolition of milk quotas, milk overproduction in the EU was on average $9.8 \%$, yet after the abolition it increased to $14.8 \%$ in 2020. In Latvia, milk overproduction in 2019 reached $39 \%$, increasing by 12\% compared with 2010 (CLAC, 2021).

Because of the pandemic, the exports of milk and dairy products from Latvia decreased by $5 \%$ to EUR 135.44 million, while the imports of dairy products decreased by $3 \%$ to EUR 89.01 million in the first half of 2020 compared with the first half of 2019. The problem with the availability of imported products in shops increased the sales of domestic products, yet the increase in domestic product sales was short-lived and unable to offset the losses suffered in the export market, as well as consumers spent more cautiously on food, incl. expensive foods.

Dairy farming in Latvia is an exporting industry, with exports increasing by $73.6 \%$ and imports by $84.9 \%$ in 2010 compared with 2010 . In this period in Latvia, the proportion of exported milk in the total milk output increased from $42.9 \%$ to $63.1 \%$. The exports of milk products are dominated by raw milk, cream and cheese, with Lithuania, Germany, Estonia and the Netherlands being the main importers, $82 \%$ of the total. Part of the raw milk exported from Latvia are later imported into Latvia as processed dairy products. On the one hand, it is a paradoxical situation, as the value added of processed milk is generated in a foreign country. The main imports were cheese, milk and cream, with $87 \%$ of the total being imported from Lithuania, Estonia and Poland.

The high proportion of imports of dairy products in total milk consumption in Latvia, which in 2010-2020 increased from $28.3 \%$ to $48.6 \%$, indicates that domestic processors have large potential in the domestic market through conducting consumer information campaigns on the benefits of purchasing domestic products and reducing the value added tax (VAT) rate on food. Support to consumers to purchase domestic food during economic tensions, incl. the pandemic, is of particular importance, as it contributes to retaining financial capital and promoting employment and overall economic stabilization in the country.

According to the data of the Ministry of Agriculture, a steady milk purchase price has been observed since 2017. Due to seasonal price changes in Latvia, the milk price increases in autumn and winter and decreases in spring and summer when the supply of milk is relatively larger. The average milk price in Latvia in 2018 and 2019 was 0.2837 and 0.2941
EUR/kg, respectively. Due to the seasonality factor, the milk price decreased in the spring of 2020 , yet due to COVID-19 the decrease was faster, from 0.3021 $\mathrm{EUR} / \mathrm{kg}$ in January to $0.2549 \mathrm{EUR} / \mathrm{kg}$ in May. In the spring of 2019, the milk price changed from 0.3021 to $0.2936 \mathrm{EUR} / \mathrm{kg}$, with the lowest annual price being observed in July, at $0.2837 \mathrm{EUR} / \mathrm{kg}$. In the autumn of 2020 , the average milk price increased to 0.2864 EUR/kg, yet it still did not reach the pre-pandemic level. The milk farmgate price might differ from the average price, as the determining factors are the constant quality of milk, the frequency of supply of milk by the farm, the distance and access to the farm, etc.

The milk farm-gate price is also determined by milk supply chains from producer to consumer. In Latvia, there are three main kinds of milk supply chains: 1) the farmer him/herself sells milk and some home-produced foods through direct marketing, 2) the producer sells milk to a local processing company, incl. to a cooperative that supplies its products to the household and business sectors in the domestic and export markets, and 3) the producer sells milk to an exporting company, incl. cooperatives that resell raw milk for processing outside Latvia. Small milk processors were able to offer higher milk purchase prices even during the pandemic by selling their products in the local market and through direct marketing, yet the quantity of the milk sold decreased. Because of the pandemic, the impacts of milk price decreases were larger for farms selling their milk to exporting buyers (global demand for industrial dairy products decreased, production costs increased and sale opportunities decreased due to closed border crossings and other difficulties in export markets) or milk processors specializing in supplying dairy products to the HoReCa as well as municipal or public sectors (schools, kindergartens, the School Milk Scheme etc.). Part of the raw milk exported from Latvia is imported into Latvia in the form of processed products, mostly from Estonia and Lithuania. A wide range of dairy products is available to consumers in Latvia, and during the pandemic, there was a change in the habits of consumers purchasing products with a longer shelf life, stockpiling food and reducing the frequency of shop visits, incl. avoiding contacts with other persons. Special attention was also paid to the price of the product, and a challenge for local producers was to sell their products at competitive prices compared with imported products and ensure products are regularly available in shops.

The decrease in milk price and milk overproduction indicate that it is not possible to regulate milk output in line with milk market trends. To stabilize the situation, the Ministry of Agriculture introduced a number of support instruments to mitigate the consequences of 
the crisis, incl. for milk supply chains - direct support to dairy farms in the amount of EUR 12.5 million and support for private storage (skimmed milk powder, cheese and butter) to processing companies.

Designing and introducing short-term and long-term measures, also those for non-pandemic conditions, an indepth analysis of risks for supply chains was performed to group the risks into groups, assess the impacts and probability of their occurrence, as well as identify appropriate risk mitigation and prevention measures. The subproject Restructuring of local agricultural and food supply chains and strengthening of resilience in crisis and post-crisis conditions in Latvia (LLU and the Institute of..., 2021) under the national research programme Covid19 Impact Mitigation identified 42 risks for milk production and processing, and identified the probability of their occurrence, and arranged the risks in a matrix according to the significance of their impacts to make recommendations on how to avoid each risk or reduce its impacts (Table 1).

Milk production and processing companies are

Table 1

Risk matrix for milk production and processing in Latvia during the COVID-19 pandemic

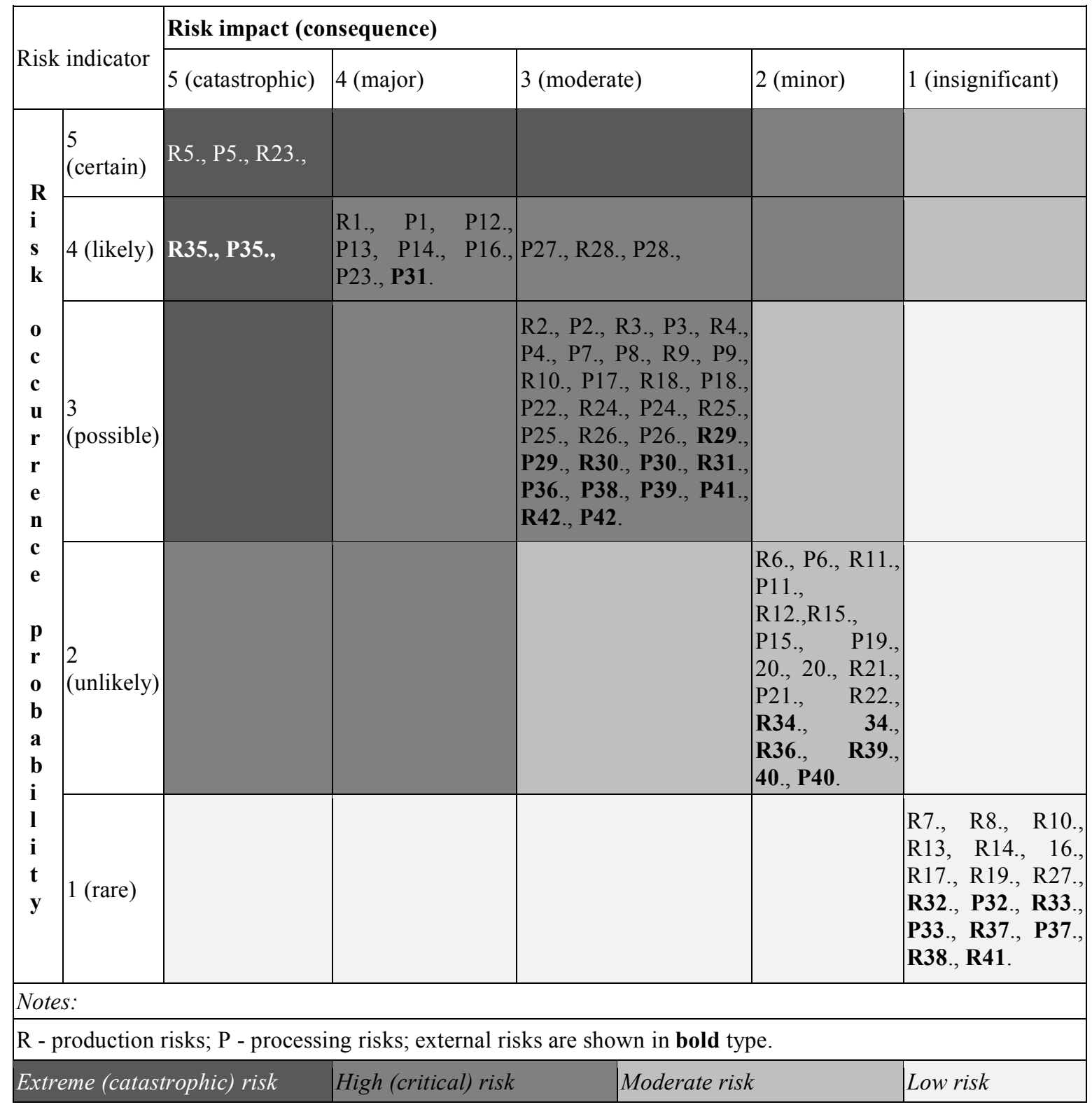

Source: authors' construction based on the Ministry of Agriculture, $2020 \mathrm{~b}$ 
significantly affected by internal risks related to the continuous operation of the company. Their number and impacts within the groups can vary according to the size of the company and the diversity of its economic activities. An analysis of potential risks in the dairy sector reveals that milk processors face a larger number of risks than dairy farmers, yet the risks need to be assessed for both sectors as a whole, as the performance of production and processing chain actors depends on the operational success of each chain link under difficult circumstances. Although an analysis of milk supply chains should include the distribution sector (shops and retail chains) during the crisis in Latvia, the distribution sector was assessed horizontally, i.e. together with all food sectors. In the distribution sector, there are no agreements with domestic producers or loyalty to domestic products in shops, and consumers choose products according to beneficial criteria, often outside Latvia because of the high VAT rate for food.

Three risks were identified in the INTERNAL risk group at the management level: 1. Difficulty in planning future economic activity; 2. Lack of experience; 3. Dependence on the driver. The most significant management risk for milk supply chains, which is possible at both the production and processing levels, is the difficulty of planning economic activity during the pandemic when there is a lot of uncertainty in the market and at the political level about the restrictions and their duration. To reduce the impacts of the risk, companies need to build up the necessary resources to ensure business continuity, as well as make additional financial savings under conditions of uncertainty, assessing each opportunity for making a saving.

At the personnel level, the following risks were identified: 4. Redundancies by closing or downsizing production facilities; 5. Dependence on the physical presence of the workforce in the company; 6. Lack of labour; 7. High personnel density; 8. Personnel contact control. Dependence on the physical presence of the workforce in the company affects both sectors, yet it is easier to ensure social distancing at production companies than at processing ones. In both sectors, companies should develop guidelines on how to organize and manage work in order to ensure social distancing and prevent disease cases in the company, as well as how to act outside the working hours to reduce the risk of disease. The work must be organized in shifts or groups so that only a part of the workforce is isolated in the event of a disease outbreak. At production companies or on farms, a solution is needed to distance the workforce from the milking pallor; however, compared with processing companies, the risk of contacts between employees is lower, yet the role of the workforce in ensuring the company's operation is the same.

Supply risks: 9. Shortage / unavailability of raw materials in the market; 10. Lack of packaging materials/supply problems; 11. Increase in raw material prices; 12. Cooperation partners under lockdown. Such risks impact mostly processing companies, as a greater variety of resources used in production is required.

At the production level, the following risks were identified: 13. Decrease in production (output); 14. Work intensity reduction/lockdown/work suspension; 15. Increase in work intensity, with the main problems being the availability of spare parts or feed additives. To mitigate the risk, it is necessary to timely identify which production resources should be imported in order to avoid their shortage in a situation of limited logistics. In addition, the companies involved in the milk supply chain do not have large financial reserves for the build-up of production resources; therefore, the possibilities to purchase these resources from domestic producers should be considered.

At the storage level, the following risks were identified: 16. Increase in stocks of manufactured products; 17. Problems with storing products with a short shelf life; 18. Freezing of current assets, and the probability of occurrence of these risks increases if the probability of occurrence of Marketing risks increases: 19. Intensification of competition with indirect competitors by not being able to compete with their direct supply and loyalty programmes; 20. Ineffectiveness of current product promotion activities in the market (e.g. food tastings, fairs, exhibitions); 21. Decrease in customer loyalty and support for products offered in local short food supply chains due to increased hygiene risks. Marketing and production risks are strongly interrelated, and at these levels most of the risks are attributable to processors that should also ensure the sale of the products. For example, the closure of HoReCa, schools and kindergartens or the situation in which other cooperation partners were under lockdown made a significant impact on companies that manufactured products in specific packaging or intermediate products. The impacts of the risks increased if companies were unable to reorient their production quickly in line with the market situation and did not have sufficient storage capacity, thereby causing additional pressure on milk supply chains and reducing their output and staffing, and farmers needed to find other raw milk buyers. To mitigate the risk impacts, additional financial resources are needed for reorienting the business to another consumer segment, and processing companies should look for an opportunity to diversify the sales of their products.

Settlement and financing risks: 22. Additional 
expenses to adapt to an emergency situation; 23. Decrease in revenue; 24. Problems to receive payments for products sold; 25. Inability to meet credit obligations; 26. Inability to cover monthly expenses; 27. Increase in logistics costs; 28. Tax debts. Settlement and financial risks make a significant impact on both producers and processors, as it relates to additional expenses, less revenue, inability to cover loan expenses and other monthly expenses. Despite the fact that processors had concluded milk purchase contracts with producers at a certain price, the milk purchase price decreased because of the pandemic, the processors lost their sales opportunities and stockpiled their products, as well as the costs related to logistics, disinfection, etc. increased. This is one of the most significant groups of risks, in the event of materialization of which the company's liquidity ratio could be improved only by means of government subsidies, deferred tax payments or loans. The dairy sector is characterized by a significant share of exports; therefore, the restrictions on external borders put the dairy sector in a difficult situation.

Risks in the EXTERNAL risk group were identified at four levels: Market risks: 29. Market uncertainty; 30. Difficulty in finding new outlets to replace closed markets; 31. Decrease/increase in demand; 32. Temporary shortage of food in the market; 33. Increase in commodity prices; 34. Decrease in customer solvency; Sectoral risks: 35. Dependence on exports; 36. Imports from EU Member States; Social risks: 37. Buyer agitation; 38. Change in buyer habits; Political and legal risks: 39. Increase in hygiene requirements for entrepreneurs; 40. Food and Veterinary Service control activities at companies; 41. Various physical restrictions at national borders; 42. Poor access to services provided by public authorities. In this risk group, major and moderate impact risks due to market and demand uncertainty were identified mostly for processors. The processors saw a solution regarding promoting domestic products through involving sectoral NGOs, encouraging consumers to choose locally produced products. In times of crisis, the price of a product is crucial for consumer choice. Producers and processors are affected by their dependence on and uncertainty in export markets, and the probability of risk occurrence is high in this case. Mitigating this risk requires a clear policy of international cooperation during the crisis, so that there is a clear action plan for the movement of food across borders in case the borders are closed.

Possible solutions to mitigating the effects of COVID-19 on milk supply chains: 1) a crisis management working group has to be established by public authorities, with the involvement of non-governmental organizations representing the dairy sector to promptly obtain information on the situation in the sector, respond to market changes and inform farmers and processors about future actions; 2) an in-depth risk analysis has to be done to assess current and future problems in order to prepare in advance for future challenges caused by the pandemic; 3 ) economic activities need to be diversified, so that a decrease in economic activity in one sector is offset by another sector without interrupting the operation of companies and maintaining employment; 4) direct support has to be provided to farmers to maintain production because in dairy farming it is impossible to stop the production process or adapt it to market conditions; 5) green corridors for international trade in food products and a legal framework for the movement of labour within and outside the country have to be available; 6) direct marketing and product baskets in accordance with changes in consumer habits have to be provided; 7) a lower VAT rate on food products, which would reduce the desire of retailers to import traditional food products, thereby reducing the amount of investment; 8) tax payment deferrals for companies so that they have more current assets in order to avoid borrowing from private banks because during the crisis there is a risk of inappropriate terms and conditions set by the banks; 9) green procurement or government-subsidized food procurement is dominated only by products of local producers; 10) private storage of food; 11) crisis management training to respond promptly and implement crisis management measures. A clear plan is needed to keep the company operational and reduce emotional stress in the company and among the public; 12) generational change is necessary, so that farms get a "new breath" and a vision for innovative solutions for future operations; 13) recipes for healthy meals developed by health specialists for daily intake of calories from low-cost essential foods for social groups with low incomes.

\section{Conclusions}

1. COVID-19 is an unprecedented case in the history of economic crises, as economic growth slowed down almost globally in the second quarter of 2020 and, unlike during other economic crises, strong coronavirus control measures were imposed during the pandemic, thereby leading to lockdown in many industries of the economy or cessation of economic activities and contributing to lower incomes and buying power, which poses a risk to the availability of sufficient and appropriate food for certain social groups.

2. In $2019,48.6 \%$ milk and dairy products consumed in Latvia were imported, mainly from countries to which the milk was exported, which indicates that 
domestic processors would have large potential in the domestic market if the non-governmental organizations of the sector promoted domestic products by explaining the common benefits to the public, as well as a reduced VAT rate on food (lower than the current $21 \%$ ) would encourage the consumption of domestic products and the substitution of imports.

3. A regular analysis of operational risks for producers and processors could make it possible to predict and prepare for future shocks to milk supply chains in the future, thereby avoiding unexpected decreases in milk purchase prices, production or employment. The risk analysis revealed that fast and efficient diversification of economic activities by the market participants involved, alignment of the products manufactured with the market demand by various customers, financial reserves for the stabilization of cash flows, the fact that impacts of the pandemic on companies with diverse partners in nearby regions are smaller and are important for the successful operation of milk supply chains.

4. Due to the pandemic, the milk purchase price decreased in Latvia in the first half of 2020 (January-May) by $15.6 \%$, which was partly offset by government support payments. Therefore, it is too early to assess the impacts of the pandemic on milk supply chains in Latvia, as there was no significant decrease in the number of cows or dairy farms compared with previous years, and the output of milk in January-May 2020 compared with 2019 was on average $2.6 \%$ lower, yet $1.9 \%$ higher in the period from May to the end of the year. The resilience of milk supply chains in Latvia will be determined by the duration of the pandemic and the resources accumulated by the participants of the sector to stabilize their cash flows.

\section{References}

Bracale, R., Vaccaro, C.M. (2020). Changes in food choice following restrictive measures due to Covid-19. Nutrition, Metabolism and Cardiovascular Diseases, Volume 30, Issue 9, 1423-1426, https://doi.org/10.1016/j.numecd. 2020.05.027.

Cavallo, C., Sacchi, G., Carfora, V. (2020). Resilience effects in food consumption behaviour at the time of Covid-19: perspectives from Italy. Heliyon, Volume 6, Issue 12, https://doi.org/10.1016/ j.heliyon.2020.e05676.

CLAL. (2021). EU-28: Milk Balance of Self-Sufficiency - Europe 2020. Retrieved: January 30, 2021, from: https://www.clal.it/en/index.php? section=ue map\&year $=2020$

CSB. (2020a). Changes in GDP compared with the 2nd quarter of 2020. Retrieved: January 22,
2021, from: https://www.csb.gov.lv/lv/statistika/ statistikas-temas/ekonomika/ikp/me$\mathrm{k} 1 \mathrm{e} \mathrm{t}-\mathrm{t}$ e m a / 2734 - i k p - a p j o ma-izmainas-2020-gada- 2-ceturksni

CSB. (2020b). Changes in GDP compared with the 3rd quarter of 2020. Retrieved: January 22, 2021, from: https://www.csb.gov.lv/lv/statistika/ statistikas-temas/ekonomika/ikp/me$\mathrm{k} 1 \mathrm{e} \mathrm{t}-\mathrm{t}$ e m a / 2776 - i k p - a p j o ma-izmainas-2020-gada- 3-ceturksni

CSB. (2020c). Grouping of farms of all kinds by the number of cattle and dairy cows at end of year. Retrieved: January 25, 2021, from: http:// data1.csb.gov.lv/pxweb/lv/lauks/lauks__05Lopk_ikgad/LLG240.px/

Elleby, C., Domknguez, I. P., Adenauer, M. \& Genovese, G. (2020). Impacts of the COVID-19 Pandemic on the Global Agricultural Markets. Environmental and Resource Economics, Volume 76,1067-1079. DOI: 10.1007/s10640-020-00473-6

Elsahoryi, N., Al-Sayyed, H., Odeh, M., McGrattan, A. \& Fwziah Hammad, F. (2020). Effect of Covid-19 on food security: A cross-sectional survey. Clinical Nutrition ESPEN, Volume 40, 171-178, https://doi.org/10.1016/j.clnesp. 2020.09.026.

European Commission. (2020). Winter 2020 Economic Forecast: Offsetting forces confirm subdued growth. Retrieved: January 14, 2021, from: https:// ec.europa.eu/commission / presscorner/detail/en/ip_20_232

Eurostat. (2021). GDP and main components. Retrieved: January 18, 2021, from: https:// ec.europa.eu/eurostat/databrowser/view/namq_10_g$\mathrm{dp} /$ default/table?lang=en

FAO \& CELAC. (2020). Food Security under COVID 19 pandemic. FAO, Rome. DOI: 10.4060/ca8873en

FAO. (2006). Changing Policy Concepts of Food Security. Policy Brief: Food Security, issue 2, 1-4.

FAO. (2009). The State of Food Security in the World: Economic crises - impacts and lessons learned. Electronic Publishing Policy and Support Branch of FAO, Rome, Italy. ISBN 978-92-5-106288-3

FAO. (2020). COVID-19 and Rural Poverty. Retrieved: January 18, 2021, from: http:// www.fao.org/family-farming/detail/ en/c/1275295/

Gross, R., Schoenenberger, H., Pfeifer, H., Preuss, H.J. (2000). The four dimensions of food and nutrition security: Definitions and Concepts. $17 \mathrm{p}$.

Hazell, P.B.R. (2009). The Asian Green Revolution. IFPRI Discussion Paper Nr. 911, Washington, USA 
IMF. (2020). World Economic Outlook Reports. Retrieved: January 14, 2021, from: https:// www.imf.org/en/Publications/WEO

IMF. (2021). Real GDP Growth. Retrieved: January 18, 2021, from: https://www.imf.org/external/ datamapper/NGDP RPCH@WEO/OEMDC/ADVEC/WEOWORLD

LLU and the Institute of Horticulture (2021). Valsts pētījumu programmas "Covid-19 seku mazināšanai" projekts Ekonomiskais, politiskais un juridiskais ietvars Latvijas tautsaimniecības potenciāla saglabāšanai un konkurētspējas pieauguma veicināšanai pēc pandēmijas izrais̄̄tas krīzes (reCOVery-LV) apakšprojekts Vietējo pārtikas ķ̧ěžu pārstrukturizēšana un noturības stiprināšana krīzes un pēckrīzes laikā Latvijā zinojums (Report on the project Towards the Post-pandemic Recovery: Economic, Political and Legal Framework for Preservation of Latvia's Growth Potential and Increasing Competitiveness (reCOVery-LV), subproject Restructuring of local agricultural and food supply chains and strengthening of resilience in crisis and post-crisis conditions in Latvia, implemented under the National Research Programme "Covid-19 Impact Mitigation"), part I, February 2021, $371 \mathrm{p}$.

OECD. (2019). OECD Economic Outlook. DOI: $10.1787 / 9 b 89401 b$-en

OECD. (2021). Quarterly GDP. Retrieved: January 18, 2021, from: https://data.oecd.org/gdp/ quarterly-gdp.htm\#indicator-chart

OECD-FAO. (2020). OECD-FAO Agricultural Outlook 2020-2029. Retrieved: December 21, 2020, from: https:/www.oecd-ilibrary.org/ agriculture-and-food/oecd-fao-agricultural-outlook-2020-2029_1112c23b-en; jsessioni d = S p 18 N c 9 M q t W S g u 5 I v DO-gJcM.ip-10-240-5-101

Pena-Levano, L., Melo, G., \& Burney, S. (2020). Theme Overview: COVID-19 and the Agriculture Industry: Labor, Supply Chains, and Consumer Behavior. Choices: The Magazine of Food, Farm, and Resource Issues, Agricultural and Applied Economics Association, vol. 35(3). DOI: $10.22004 /$ ag.econ.305274

Perrin, A. \& Martin, G. (2021). Resilience of French organic dairy cattle farms and supply chains to the Covid-19 pandemic. Agricultural Systems, Volume 190, May 2021, https://doi.org/ 10.1016/ j.agsy.2021.103082.

Siche, R. (2020). What is the impact of COVID-19 disease on agriculture? Scientia Agropecuaria 11(1), 36. DOI: 10.17268/sci.agropecu.2020.01.00

Statista. (2021). Quarterly gross domestic product (GDP) growth rate in China. Retrieved: January 18, 2021, from: https:/www.statista.com/statistics/ $271769 /$ quarterly-gross-domestic-product-gdp-growth-rate-in-china/

TAG. (2020.) Maintaining Food Safety in the COVID-19 Era. The Acheson Group, retrieved: January 20, 2021, from: https:// achesongroup. com/maintaining-food-safety-in-the-covid-19-era/

Wang, Q., Liu, Ch., Zhao, Y., Kitsos, A., Annella, M., Wang, Sh., Han, L. (2020). Impacts of the COVID-19 pandemic on the dairy industry: Lessons from China and the United States and policy implications. Journal of Integrative Agriculture, Volume 19, Issue 12, 2903-2915, https://doi.org/10.1016/S2095-3119(20)63443-8.

World Bank. (2021). Global Economic Prospects, January 2021. DC: World Bank, Washington. DOI: 10.1596/978-1-4648-1612-3.

World Health Organization. (2020). Coronavirus disease (COVID-19) Weekly Epidemiological Update and Weekly Operational Update. Retrieved: December 18, 2020, from: https:// www.who.int/emergencies/diseases/novel-coronavirus-2019/situation-reports

Ministry of Agriculture. (2020a). Covid-19 pandēmija turpina nelabvēlīgi ietekmēt lauksaimniecības un pārtikas ražošanas nozares, EK jābūt gatavai atbilstoši reaǵêt (The Covid-19 pandemic continues to adversely impact the agricultural and food industries, and the EC should be ready to respond accordingly). Retrieved: January 24, 2021, from: https://www.zm.gov.lv/zemkopibas-ministri$\mathrm{ja} / \mathrm{presei}$ /covid-19-pandemija-turpinanelabveligi-ietekmet-lauksaimniecibas-un-pa?id=11837

Ministry of Agriculture. (2020b). Latvijas lauksaimniecība - 2020. gada ziņojums par 2019. gadu (Agriculture in Latvia - a 2020 Report for 2019). Retrieved: January 24, 2021, from: https://www.zm.gov.1v/lauksaimnieci$\mathrm{b}$ a / s t a t i s k a s - 1 a p a s / 1 a u k saimniecibas-gada-zinojumi?nid=531\#jump

\section{Acknowledgement}

The paper was supported by the National Research Programme "Towards the Post-pandemic Recovery: Economic, Political and Legal Framework for Preservation of Latvia's Growth Potential and Increasing Competitiveness" (reCOVery-LV), Project Agreement: VPP-COVID-2020/1-0010. 